удК $347.73 ; 342.55$

DOI https://doi.org/10.32837/apdp.v0i83.133

С. А. Семенченко

\title{
ДО ПИТАННЯ ПРАВОВОЇ ПРИРОДИ МІСЦЕВИХ БЮДЖЕТІВ
}

Постановка проблеми. Сучасний етап соціально-економічного розвитку нашої країни потребує поглибленого розуміння ролі місцевих бюджетів як визначальної ланки місцевих фінансів. Для цього їх слід розглядати не тільки як балансові розрахунки доходів і витрат, що мобілізуються і витрачаються на відповідній території, а й як важливу правову та економічну категорію. Місцеві бюджети забезпечують фінансування більшості бюджетних видатків, тому є одним із основних джерел задоволення життєвих потреб громади. Це, передусім, виплати із соціального захисту населення, утримання закладів соціально-культурної сфери, охорони здоров'я, видатки на розвиток і оновлення інфраструктури, ремонт і утримання автомобільних доріг комунальної власності тощо.

Запровадження Концепції реформування місцевого самоврядування та територіальної організації влади в Україні, затвердженої розпорядженням Кабінету Міністрів України від 01.04.2014 № 333-р [1], та створення законодавчої бази для діяльності органів місцевого самоврядування на новій територіальній основі з визначенням повноважень та їх ресурсного забезпечення, призвело до утворення нового учасника бюджетних відносин - об'єднаних територіальних громад. Зазначені зміни знайшли своє відображення у положеннях стосовно структури бюджетної системи, які включені до Бюджетного кодексу України, оскільки мають концептуальне і практичне значення для забезпечення ефективності бюджетного процесу та конкретизують його понятійний апарат.

Метою статті $є$ проведення теоретичного узагальнення наукових досліджень 3 визначення термінів «бюджет», «місцеві бюджети» та «бюджети місцевого самоврядування», визначення їх структури та природи.

Виклад основного матеріалу дослідження. Необхідність правильного визначення та розуміння того чи іншого поняття зумовлюється розвитком національної правової системи, а також змінами в предметі правового регулювання. У фінансовій теорії і практиці існують різні підходи до визначення природи бюджетів, трактуванні понять «бюджет» $\mathrm{i}$ «місцевий бюджет», що обумовлено їх багатогранністю. Так, зокрема, науковці зазначають, що бюджет є «невід’ємним атрибутом кожної країни та важливим інструментом реалізації економічної та соціальної політики» [2, с. 12], «основним ресурсом, що забезпечує можливість виконання державою своїх функцій, реалізації конституційних прав і свобод» [3, с. 3].

Розуміння бюджету як ресурсу притаманне як поглядам вчених, так і законодавця. Так, ст. 2 Бюджетного кодексу України [4] визначає бюджет як план формування та використання фінансових ресурсів для забезпечення завдань і функцій, які здійснюються відповідно органами державної влади, органами влади Автономної Республіки Крим, органами місцевого самоврядування протягом бюджетного періоду. Є.С. Овсянніков слушно зазначає, що такий підхід дозволяє розглядати 
бюджет на рівні його управлінського значення, однак залишає поза увагою правове його розуміння і майже не торкається економічної сутності бюджету. Також виникають питання щодо вживання словосполучення «фінансові ресурси», оскільки, по-перше, не визначено зміст такого терміну, по-друге, у бюджет можуть зараховуватись і витрачатись лише грошові кошти [5, с. 23-24].

Дійсно, беззаперечно погодитись із запропонованим вітчизняним законодавцем визначенням бюджету складно через природу ресурсів. Фактично під поняттям «ресурси» розуміється сукупність грошей, майна, виробничих об'єктів тощо, але навряд чи в такому сенсі слід ставити знак рівності між бюджетом і ресурсами. Не можна ототожнювати навіть такі поняття, як «бюджет» і «фінансові ресурси» .

Бюджет на будь-якому рівні (держави чи територіальних громад) охоплює виключно грошові кошти і найбільш стисле його визначення якраз і передбачає наявність такої ключової смислової складової, як «централізований грошовий фонд». Бюджет - це за своєю природою кошторис, який узгоджує грошові надходження до дохідної частини та грошові витрати з видаткової. Саме тому визначення бюджету має будуватися виключно через характеристику його як плану, сукупності, поєднання та витрачання централізованих грошових фондів.

Найчастіше під бюджетом розуміють фонд грошових коштів, за рахунок якого здійснюється відповідне фінансування. Коли мова йде про бюджет на стадіях складання і виконання, він розуміється як фінансовий план, або як кошторис чи розпис доходів і видатків. Стосовно останнього слушною є думка професора I.X. Озерова, який у своїй роботі «Основи фінансової науки» [6] наголошував на розбіжностях між поняттями «бюджет» $\mathrm{i}$ «розпис». Співвідношення розпису з бюджетом учений розумів як співвідношення частини і загального, вважаючи розпис лише додатком бюджетного закону до конкретного випадку.

Коли ж йдеться про оформлення, тобто про затвердження відповідними органами місцевого самоврядування проекту бюджету, він трактується вже як акт, що встановлює фінансовий план. Як вірно зазначає О.А. Музика-Стефанчук, будьякий акт про бюджет є зовнішнім оформленням бюджету, а тому не слід ототожнювати бюджет і акт про бюджет, оскільки бюджет у власному розумінні не $є$ і не може бути законом [7, с. 10]. Таких підхід стосовно місцевих бюджетів знаходить відображення у законодавстві.

Так, у ст. 2 Бюджетного кодексу України поряд із визначенням місцевих бюджетів, бюджетів місцевого самоврядування та бюджетів об'єднаних територіальних громад законодавець надає також визначення рішення про місцевий бюджет, як нормативно-правового акта Верховної Ради Автономної Республіки Крим чи відповідної місцевої ради, виданий в установленому порядку, що затверджує місцевий бюджет та визначає повноваження відповідно Ради міністрів Автономної Республіки Крим, місцевої державної адміністрації або виконавчого органу місцевого самоврядування здійснювати виконання місцевого бюджету протягом бюджетного періоду. Таким чином, законодавчо закріплено співвідношення як бюджету відповідної територіальної громади, так і акта про місцевий бюджет, виданий місцевою радою.

Принагідно варто зауважити, що стосовно державного бюджету подібного співвідношення у Бюджетному кодексі України не передбачено, оскільки відсут- 
нє визначення поняття «Державний бюджет України», надано лише визначення закону про Державний бюджет України як закону, який затверджує Державний бюджет України та містить повноваження щодо забезпечення його виконання протягом бюджетного періоду.

У науці категорія «бюджет» традиційно розглядається у двох аспектах - економічному і правовому (юридичному). При цьому М.I. Піскотін виділяв три значення, в яких практично використовується термін «бюджет» [8, с. 20]. На думку вченого, бюджет розуміється як фінансовий план держави коли береться до уваги питання складання, прийняття і виконання бюджету. За другим значенням під бюджетом мають на увазі фонд грошових коштів, з яких відбувається покриття державних видатків. Третє значення терміну «бюджет» розкривається у зв’язку з його офіційним оформленням. «Фінансовий план держави, розроблений її виконавчо-розпорядницькими органами, не є бюджетом як таким. Поки його не затверджено вищим органом державної влади, він є лише проектом бюджету та отримує високий титул бюджету тільки у результаті офіційного затвердження. В цьому випадку під бюджетом розуміється вже державний акт, що встановлює фінансовий план держави».

На думку Л.К. Воронової, оскільки бюджет відіграє різну роль у житті кожної країни, його можна розглядати також і в таких аспектах:

1) матеріальному - як документ, в якому об'єднуються доходи і видатки держави або органу місцевого самоврядування;

2) адміністративному - як попередній план доходів і видатків;

3) бухгалтерському - як зведену таблицю зібраних доходів і видатків (за класифікацією доходів і видатків);

4) політичному - як дозвіл законодавчого (або місцевого представницького) органу на формування і використання державних (і місцевих) фінансових ресурсів;

5) соціальному - як інструмент впливу держави або органу місцевого самоврядування на соціальне життя країни [9, с. 111-112].

Вчена зазначає, що з економічного боку бюджет являє собою сукупність суспільних (економічних) відносин, що зумовлені об'єктивно існуючими товарно-грошовими відносинами і дією закону вартості, за допомогою яких відбувається розподіл національного доходу і утворення централізованих фондів коштів. Л.К. Воронова також наголошує, що поняття бюджету як економічної категорії не пов'язане з його офіційним оформленням, тобто з поняттям бюджету як правової категорії [10, с. 9-10].

Правовий аспект категорії «бюджет» зумовлений юридичною формою регулювання бюджетних відносин. М.П. Кучерявенко зазначає, що бюджет, як правова категорія, становить правовий акт, основний фінансовий план створення, розподілу й використання централізованого грошового фонду держави або територіальної громади [11, с. 98]. Затвердження бюджету у формі відповідного нормативно-правового акта є важливою умовою забезпечення законності у сфері бюджетних відносин.

За визначенням O.I. Худякова, бюджет як правова категорія - це фінансово правовий акт, за допомогою якого затверджується фінансовий план формування та розподілу державного грошового фонду, що створюється на державному та місцевому рівнях та призначений для фінансування загальнодержавних завдань 
і функцій [12, с. 10]. У правовому розумінні бюджет є фінансовим планом формування та використання коштів, що затверджується за встановленою процедурою відповідним представницьким органам і є обов'язковим для виконання на визначеній території.

Л.К. Воронова звертає увагу на правове призначення бюджету, яке на думку вченої полягає в тому, що «він надає органам влади, що його затверджують, можливість вищого постійного керівництва в галузі фінансової діяльності, контролю діяльності виконавчо-розпорядчих органів, які складають і виконують бюджет» $[10$, с. 9]. Відповідно, правове значення бюджету виникає одночасно із реалізацією повноважень публічних органів влади щодо його затвердження.

На думку О.П. Гетьманець, правове значення бюджету має двояку характеристику. 3 одного боку, закон або рішення ради регіональних органів затверджує план формування, розподілу та використання державних фінансових ресурсів, тобто ні джерела доходів, ні їх суми, ні напрямки та обсяги використання не можуть бути ніякими іншими, а тільки тими, що вказані в цьому юридичному акті. 3 іншого правове значення бюджету полягає в тому, що юридичний акт про бюджет надає органам державної влади повноваження щодо керування фінансовим господарством України та її регіонами, а також щодо контролювання бюджетної діяльності.

Нормативно-правові акти про бюджет установлюють права та обов'язки органів виконавчої влади держави і на місцях щодо формування, розподілу та використання бюджетних коштів і зобов'язують ці органи їх виконувати, дозволяють відповідним керівникам надавати бюджетні асигнування, брати бюджетні зобов'язання, які мають конкретно-адресний характер. Таким чином, правове призначення бюджету полягає у встановленні законності в отриманні та використанні державних грошей, у державному управлінні централізованими грошовими фондами у країні та в регіонах [13, с. 148-149].

Узагальнюючи визначення місцевих бюджетів у фінансовій літературі, слід звернути увагу на відсутність єдиного підходу, що обумовлено їх багатоаспектністю як складного суспільно-економічного та правового явища. Розгляд питання трактування та визначення категорії «місцеві бюджети» відбувається відповідно до обраного науковцями кута дослідження. Так, найчастіше місцеві бюджети розглядають як: 1) економічну категорію (систему економічних відносин); 2) правову категорію (нормативний документ); 3) фонд фінансових ресурсів (грошовий фонд); 4) план доходів та видатків (кошторис); 5) бюджет адміністративно-територіальної одиниці; 6) інструмент перерозподілу суспільного продукту; 7) частину бюджетної системи (найчисельнішу складову бюджетної системи) [14, с. 127]

У монографії «Правове регулювання місцевих фінансів в Україні» [15] термін «місцевий бюджет» запропоновано визначити як «план формування та використання фінансових ресурсів публічного грошового фонду на виконання завдань і функцій, які здійснюються органами місцевого самоврядування з метою задоволення публічних потреб населення відповідної адміністративно-територіальної одиниці» [15, с. 127-128]. Погоджуючись загалом із таким визначенням, варто зауважити, що виконання завдань і функцій для задоволення публічних потреб населення здебільшого покладено на органи місцевої влади - структурні підрозді- 
ли обласної державної адміністрації, які відповідно до рішення місцевої ради про бюджет визначені головними розпорядниками коштів за відповідними бюджетними програмами.

В.Г. Дем'янишин та А.К. Малярчук, виділяючи правовий характер місцевих бюджетів, зазначають, що «рішення сесій місцевих рад про затвердження відповідних місцевих бюджетів є правовим (нормативним) документом, який зобов'язані виконувати всі юридичні та фізичні особи, пов'язані з дохідною та видатковою частиною цих бюджетів. За невиконання цього документа передбачена відповідальність, яку можуть нести відповідні порушники, включаючи й кримінальну відповідальність» [16, с. 16 -17]. Не можна беззаперечно погодитись із таким твердженням. По-перше, фізичні особи не можуть розглядатися як суб'єкти бюджетних правовідносин, оскільки особливістю бюджетно-правового регулювання є відсутність фізичних осіб як учасників, щодо яких спрямовані бюджетно-правові приписи. Безумовно, може йтися про Президента України, який підписує Закон про Державний бюджет України, про розпорядників бюджетних коштів, але це не фізичні особи. Президент України в бюджетних відносинах уособлює орган влади. Розпорядники бюджетних коштів - бюджетні установи в особі їх керівників, а не окрема фізична особа як суб’єкт бюджетного права. По-друге, відповідальність може наступати, у тому числі і кримінальна, але не за невиконання цього документа (рішення сесії місцевих рад), а за вчинені порушення бюджетного законодавства (саме так називається глава 18 Бюджетного кодексу України).

Кожна країна залежно від історичних традицій, форми держави та соціальноекономічних умов будує власну бюджетну систему. Визначення бюджетної системи України закріплено в кодифікованому акті бюджетного законодавства. Так, відповідно до ст. 2 Бюджетного кодексу України зміст поняття «бюджетна система України» включає в себе сукупність державного бюджету та місцевих бюджетів, що побудована з урахуванням економічних відносин, державного і адміністративно-територіальних устроїв і врегульована нормами права. Автор зауважує, що наразі структура бюджетної системи України (до складу якої входять бюджети об'єднаних територіальних громад) не узгоджується з нормами про адміністративно-територіальний устрій, які закріплені в Основному Законі України (ст. 133) [17].

Процес фундаментальних змін системи місцевого самоврядування та бюджетних відносин, який розпочався в Україні з 2014 року, призвів до утворення нового потужного суб'єкта місцевого самоврядування - об'єднаних територіальних громад. Законом України від 10.02.2015 № 176-VIII «Про внесення змін до Бюджетного кодексу України та деяких інших законодавчих актів України» [18]були внесені відповідні зміни до структури бюджетної системи України, а саме доповнено перелік бюджетів місцевого самоврядування окремою ланкою бюджетами об'єднаних територіальних громад. При цьому, доповнення понятійного апарату кодифікованого акту вітчизняного бюджетного законодавства дефініцією «бюджети об’єднаних територіальних громад» відбулося значно пізніше згідно із Законом України від 07.12.2017 № 2233-VIII «Про внесення змін до Бюджетного кодексу України» [19]. Законом також унормовано питання щодо включення бюджетів об'єднаних територіальних громад до показників зведеного бюджету області (частина четвер- 
та ст. 6 Бюджетного кодексу України). Тоді як у старій редакції зазначалося, що показники бюджетів ОТГ включаються до відповідного зведеного бюджету без конкретного визначення, до якого саме бюджету.

Отже, відповідно до ст. 5 Бюджетного кодексу України структура бюджетної системи України складається з державного бюджету та місцевих бюджетів. До місцевих бюджетів віднесено бюджет Автономної Республіки Крим, обласні, районні бюджети та бюджети місцевого самоврядування. Бюджети місцевого самоврядування визначено як бюджети територіальних громад сіл, їх об'єднань, селищ, міст (у тому числі районів у містах), бюджети об'єднаних територіальних громад. У свою чергу, до бюджетів об'єднаних територіальних громад віднесено бюджети об'єднаних територіальних громад, створених згідно із законом та перспективним планом формування територій громад, а також бюджети об'єднаних територіальних громад, визнаних Кабінетом Міністрів України спроможними в порядку, встановленому законом.

За загальним правилом, в унітарних країнах поняття «місцевий бюджет» збігається з поняттям «бюджет місцевого самоврядування». У федеративних країнах до системи місцевих бюджетів входять бюджети суб'єктів федерації та бюджети адміністративно-територіальних утворень, на які поділяється відповідний суб'єкт федерації. В Україні бюджети територіальних громад сіл, їх об’єднань, селищ, міст (у тому числі районів у містах), бюджети об’єднаних територіальних громад входять до складу бюджетів місцевого самоврядування, що не заважає їм бути за природою місцевими.

Аналізуючи інші акти чинного законодавства України на предмет визначення місцевих бюджетів, необхідно звернути увагу на Закон України «Про місцеве самоврядування в Україні» [20], в якому поняття «місцевий бюджет» та «бюджет місцевого самоврядування» ототожнюються. Так, у статті 1 Закону України «Про місцеве самоврядування в Україні» бюджет місцевого самоврядування (місцевий бюджет) трактується як план утворення і використання фінансових ресурсів, необхідних для забезпечення функцій та повноважень місцевого самоврядування. Автор вважає такий підхід помилковим, оскільки він суперечить положенням Бюджетного кодексу України, нормами якого бюджети місцевого самоврядування визначено як складову місцевих бюджетів. Також у зазначеному Законі містяться визначення таких понять як «районний бюджет», «обласний бюджет», «поточний бюджет», «бюджет розвитку», при цьому у кодифікованому акті бюджетного законодавства України відсутнє визначення цих термінів. Для усунення суперечностей при застосуванні законодавчих норм необхідно відкоригувати визначення понять, що міститься в Законі України «Про місцеве самоврядування в Україні», шляхом узгодження їх із нормами Бюджетного кодексу України.

Щодо підстав для розмежування бюджетів на місцеві та бюджети місцевого самоврядування, слід погодитись із вітчизняною вченою Д.К. Мітрофановою, яка підставами для такого поділу визначає не тільки адміністративно-територіальний устрій України, а й повноваження певних органів влади щодо їх прийняття і виконання, а також особливості формування їх дохідної частини [21, с. 30-31]. У цьому контексті виділяється те, що бюджети місцевого самоврядування само- 
стійно розробляють, затверджують і виконують відповідні органи місцевого самоврядування в селах, селищах, містах, об'єднаних територіальних громадах (місцеві ради та їх виконавчі органи або сільські голови, якщо відповідні виконавчі органи не створені, у порядку визначеному главою 12 Бюджетного кодексу України). Щодо решти місцевих бюджетів, то участь представницьких органів влади Верховної Ради Автономної Республіки Крим, відповідних обласних та районних рад - обмежено лише затвердженням місцевих бюджетів, внесенням змін до рішень про місцевий бюджет та затвердженням звітів про їх виконання. Складання і виконання таких місцевих бюджетів покладається на Раду Міністрів Автономної Республіки Крим та відповідні місцеві державні адміністрації згідно з Бюджетним кодексом України.

Наведена відмінність між місцевими бюджетами та бюджетами місцевого самоврядування має важливе практичне значення для бюджетної системи України, а через неї - для всієї держави в цілому. Це, перш за все, обумовлено тим, що «бюджети місцевого самоврядування відрізняються від інших місцевих бюджетів своєю первинністю, яка полягає у можливості акумулювання значної частини надходжень від власних джерел територіальних громад - місцевих податків та зборів, які встановлюються органами місцевого самоврядування відповідно до статті 10 Податкового кодексу України, і виступають як матеріальною і фінансовою основою місцевого самоврядування, так і одним із способів здійснення народовладдя в Україні, що разом є запорукою реалізації основних конституційних засад територіального устрою, гарантій місцевого самоврядування» [21, с. 33].

Висновки. Місцеві бюджети є багатогранним поняттям, яке не можна віднести лише до однієї категорії, а необхідно розглядати як сукупність правового та економічного регулювання. Правова природа місцевого бюджету зумовлена юридичною формою регулювання бюджетного процесу на місцевому рівні.

У правовому розумінні місцевий бюджет є фінансовим планом формування та використання коштів, що затверджується у встановленому порядку рішенням відповідної місцевої ради і є обов'язковим для виконання на певній території. Лише з моменту прийняття законодавчого акта (рішення) виникають відповідні бюджетні права та обов'язки учасників відносин, засоби, які забезпечують їх дотримання, можливість застосування примусу у разі порушення відповідної норми.

\section{Jimepamypa}

1. Про схвалення Концепції реформування місцевого самоврядування та територіальної організації влади в Україні: розпорядженням Кабінету Міністрів України від 01.04.2014, № 333-р // Офіц. вісн. України. 2014. № 30. Ст. 831.

2. Клець Л. Є. Бюджетний менеджмент : навч. посіб. / Л.Є. Клець. К. : Центр учбової л-ри, $2007.640 \mathrm{c}$.

3. Клишина М.А. Составление проекта бюджета как стадия бюджетного процесса : автореф. дис. на соискание науч. степени канд. юрид. наук: спец. 12.00.14 «Административное право, финансовое право, информационное право» / М.А. Клишина. М. : 2009. 29 с.

4. Бюджетний кодекс України від 08 липня 2010 року // Відомості Верховної Ради України. 2010. № 59. Ст. 2047.

5. Овсянніков Є.С. Правове регулювання виконання бюджетів за видатками в Україні : дис. ... канд. юрид. наук: 12.00.07 / Овсянніков Євген Сергійович; Ун-т Держ. фіскал. служби України. Ірпінь, 2017. $231 \mathrm{c.}$ 
6. Озеров И.Х. Основы финансовой науки: вып. ІІ: [Бюджет. Формы взимания. Местные финансы. Государственный кредит] / И.Х. Озеров. М. : Общ-во взаимопомощи студентов-юристов Моск. ун-та, 1905. $333 \mathrm{c}$.

7. Музика О.А. Доходи місцевих бюджетів за українським законодавством : монографія / О.А. Музика. К. : Атіка, 2004. 344 с.

8. Пискотин М.И. Советское бюджетное право / М.И. Пискотин. Москва : Юрид. лит., 1971. 312 с.

9. Воронова Л.К. Фінансове право України : [підручник] / Л.К. Воронова. К. : Прецедент; Моя книга, 2006. 448 с.

10. Воронова Л.К. Бюджетно-правове регулювання в СРСР / Л.К. Воронова. К. : Вища шк., 1975. 183 с.

11. Фінансове право України : [підручник] / Г.В. Бех, О.О. Дмитрик, І.Є. Криницький; за ред. М.П. Кучерявенка. К. : Юрінком Інтер, 2004. 320 с.

12. Худяков А.И. Финансовое право Республики Казахстан: Особенная часть : [Учебник] / А.И. Худяков. Алматы : НОРМА-К, 2002. 344 с.

13. Фінансове право : підручник / за заг. ред. О.П. Гетманець; [Бандурка О.М., Гетманець О.П., Жорнокуй Ю.М. та ін.]; МВС України, Харків. нац. ун-т внутр. справ. Харків, 2017. 392 с.

14. Теоретико-системні основи визначення місцевих бюджетів / Ю.О. Раделицький // Причорноморські економічні студії. 2017. Вип. 14. С. 125-130.

15. Правове регулювання місцевих фінансів в Україні / [Солдатенко О.В., Антипов В.І., Музика-Стефанчук О.А. та ін.]; за заг. ред. О.В. Солдатенко. К. : Алерта, 2011. 244 с.

16. Дем'янишин В. Концептуальні засади місцевих бюджетів / В. Дем'янишин, А. Малярчук // Світ фінансів. 2006. № 1. С. 5-18.

17. Конституція України від 28 червня 1996 р. № 254к/96-ВР // Відом. Верхов. Ради України. 1996. № 30. Ст. 141.

18. Про внесення змін до Бюджетного кодексу України та деяких інших законодавчих актів України : Закон України від 10 лют. 2015 р. № 176-VIII // Офіційний вісник України. 2015. № 18. Ст. 475.

19. Про внесення змін до Бюджетного кодексу України : Закон України від 07 груд. 2017 р. № 2233-VIII // Відомості Верховної Ради України. 2018. № 2. Ст. 8.

20. Про місцеве самоврядування в Україні : Закон України від 21 трав. 1997 р. // Офіційний вісник України. 1997. № 25. Ст. 20.

21. Мітрофанова Д.К. Правове регулювання виконання Державного бюджету України за доходами : дис. ... канд. юрид. наук: 12.00.07 / Д.К. Мітрофанова. Харків, 2013. 212 с.

\section{Анотація}

Семенченко С. А. До питання правової природи місцевих бюджетів. - Стаття.

У статті розкрито основні підходи до визначення поняття «бюджет» як складного економічного та правового явища. розуміння бюджету як ресурсу притаманне як поглядам вчених, так і законодавця. Проаналізовано ст. 2 Бюджетного кодексу України, яка визначає бюджет як план формування та використання фінансових ресурсів для забезпечення завдань і функцій, які здійснюються відповідно органами державної влади, органами влади Автономної Республіки Крим, органами місцевого самоврядування протягом бюджетного періоду.

Проаналізована думка Є.С. Овсяннікова, який слушно зазначає, що такий підхід дозволяє розглядати бюджет на рівні його управлінського значення, однак залишає поза увагою правове його розуміння і майже не торкається економічної сутності бюджету. Розкрито питання щодо вживання словосполучення «фінансові ресурси», які автор детально розкрив у статті.

Мета статті - проведення теоретичного узагальнення наукових досліджень з визначення термінів «бюджет», «місцеві бюджети» та «бюджети місцевого самоврядування», визначення їх структури та природи. Проаналізовано зміни до бюджетного законодавства в частині структурних складових юджетної системи України.

Досліджено сутність правової природи місцевих бюджетів. Проаналізоване бачення О.П. Гетьманця, що правове значення бюджету має двояку характеристику. Проаналізувавши інші акти чинного законодавства України на предмет визначення місцевих бюджетів, автор звернув увагу на Закон України «Про місцеве самоврядування в Україні», в якому поняття «місцевий бюджет» та «бюджет місцевого самоврядування» ототожнюються. Наведена відмінність між місцевими бюджетами та бюджетами місцевого самоврядування має важливе практичне значення для бюджетної системи України, а через неї - для всієї держави в цілому.

Ключові слова: бюджет, бюджетна система, місцеві бюджети, органи місцевого самоврядування, об’єднані територіальні громади. 


\section{Summary}

Semenchenko S. A. To the question of legal nature of local budgets. - Article.

The article describes the main approaches to defining the concept of "budget" as a complex economic and legal phenomenon. understanding the budget as a resource is inherent in the views of scientists and legislators. Analyzed Art. 2 of the Budget Code of Ukraine, which defines the budget as a plan for the formation and use of financial resources to ensure the tasks and functions, which are carried out respectively by public authorities, authorities of the Autonomous Republic of Crimea, local self-government bodies during the budget period.

The opinion of E.S. Ovsyannikov, who rightly notes that this approach allows to consider the budget at the level of its managerial importance, but leaves aside its legal understanding and almost does not affect the economic essence of the budget. The article deals with the use of the phrase "financial resources", which the author has explained in detail in the article. The purpose of the article is to carry out a theoretical generalization of scientific research on the definition of the terms "budget", "local budgets" and "local government budgets", definition of their structure and nature.

Changes to the budget legislation in terms of structural components of the budget system of Ukraine are analyzed. The nature of the legal nature of local budgets is investigated. OP's vision analyzed Hetman that the legal significance of the budget has a dual characteristic. Having analyzed other acts of the current legislation of Ukraine concerning the definition of local budgets, the author drew attention to the Law of Ukraine "On Local Self-Government in Ukraine", in which the terms "local budget" and "local government budget" are combined. The above distinction between local budgets and local government budgets is important for the budget system of Ukraine, and therefore for the whole country as a whole.

Key words: budget, budget system, local budgets, local governments, united territorial communities. 